\title{
INTERNATIONAL TERRORISM AND ORGANIZED CRIME IN BALKANS - AN ATTEMPT TO DIAGNOSE THE PHENOMENON
}

\begin{abstract}
... war, the disintegration of states, distribution systems, economic and financial crises, this is the element of the Mafia and its natural environment. It is a parasite that preys on the sick organism. And the world is the subject of globalization never to be healthy. The Mafia, just as terrorism, can be eliminated in only one way: with Stalinism. This would be the equivalent of treating influenza with cholera. And you can not cure cancer because.
\end{abstract}

K. Mroziewicz

\section{Terrorism - introduction}

The phenomenon of terrorism in the modern world clearly embodies the imperfections of the functioning of global systems of governance ${ }^{1}$, both in terms of internal and international security. This can be demonstrated using the examples of crimes incited by hatred which according to the authorities are responsible for the breakdown I global law and order, which should never have occurred. Unfortunately, crimes appear frequently and do worry the most powerful people on the globe.

Terrorism is the phenomenon electrifying world's public opinion, conditioning and increasing the huge potential for heightened fear, anxiety and helplessness among the representatives of the global population, mainly due to the fact that individual acts of terrorism can happen anywhere and touch upon each citizen regardless of circumstances or where they reside.

1 See more: R. Thakur, Security in the new millenium, (w:), Ehancing Global Governance; towards a new diplomacy?, (ed:), A.F. Cooper, j. English, R. Thakur, The United Nations University 2002, p. 270. 
Numerous accounts appear in the literature of efforts to identify, diagnose, define and finally to discover, the causative mechanisms of modern terrorism ${ }^{2}$. The consequence of those efforts was the development of effective ways to combat the hazardous phenomenon of terrorism. However, and despite the painstaking research conducted by centers dealing with criminal issues around the world, there is still no universal definition of terrorism. What is more, there are more than two hundred such centres ${ }^{3}$ and each gives its own, frequently modified approach to the subject matter.

\section{Terrorism - the multiplicity of definitions}

Attempts to develop an universally accepted definition of terrorism has been repeatedly presented to the $\mathrm{UN}$, however, the discussions have not led to any meaningful and constructive conclusions. Some experts, penetrating the theme of terrorism deeper, argue that it is not possible to create a comprehensive definition of terrorism as it is a synthetic definition of various forms of politically motivated violence ${ }^{4}$.

Moreover, the situation becomes complicated by the fact that contrary to public expectations, it is difficult to enforce law even if it is based on the most perfect definition. The definition of terrorism should also identify the motives, goals and intentions of the perpetrators of crimes incited by hatred. In this connection, the Polish legislator decided not to isolate this new form of crime by defining its own essence 5 .

Provisions for acts of terrorism in Polish penal law (Penal Code) include various parts of the above and have a general profile ${ }^{6}$. Furthermore, they have to stay consistent with international law applicable in this field and have to emphasize their universal character. The considerations stated above clearly show that the phenomenon of terrorism is multidimensional, multifaceted and of multi-character. Therefore, it is the subject of scientific inquiry, appearing in various fields of study.

I. Bantekas, S. Nash, International criminal law, London 2003, p. 17-46.

K. Jałoszyński, Zagrożenie terroryzmem w wybranych krajach Europy Zachodniej oraz w Stanach Zjednoczonych, Warszawa 2001, p. 8.

W. Laquer, The Age of Terrorism, Boston Little, Brown 1987, K. Karolczak, Encykolpedia terroryzmu, Warszawa 1995, p. 9.

I. Pospiszyl, Patologie społeczne, Warszawa 2010, p. 92.

Chapters XVI. Crimes against peace, humanity and war crimes (Articles 118-121), XVII. Crimes against the Polish Republic (Art. 127, 128), XVIII. Offences against the defense (Article 140), XX. Offences against public safety (Articles 163-168), XXI. Offences against the security of the communication (Art. 173, 175), XXIII. Offences against liberty (Article 189), XXIX, Crimes Crimes against the activities of state institutions and local government (art. 223) (art. 223), XXX. (Article 232), xxxii. Offences against public order (Article 252), XXXIII, Crimes against protection of information, S. Pikulski, Prawne środki zwalczania terroryzmu, Olsztyn 2000, pp. 25-50. 
The genesis of terrorism is trying to unravel by examining inter alia the motivation of terrorists. The most common motives are economic, political, moral and ideological.

On the level of theoretical considerations, terrorism is tested by the use of the following concepts: terrorism as a weapon of the weak ${ }^{7}$, terrorism as a response to economic and social inequalities ${ }^{8}$, terrorism as a mean of sharing power ${ }^{9}$, terrorism as a result of the clash of civilizations ${ }^{10}$, and terrorism as a result of infringement of the balance of ideals in the world.

Seeking a non-legal ${ }^{11}$ explanation on the concept of terrorism, a lot of attention is given to the works of $\mathrm{J}$. Baudrillard ${ }^{12}$ who proves that terrorism has arise from the violation of equilibrium in the world of ideals. The author concludes that the coexistence of stability and social reality provides perfect harmony between good and evil. The dominance of any ideal will automatically launch opposite forces to depose it.

Baudillard notes that the phenomenon of terrorism is a kind of riposte for the dominant civilization in the countries of Western philosophy, rationalism, pragmatism and utilitarianism. Furthermore, the author explains and cites that "when power is growing into strength, the destruction also increases"13. "For today's terrorists, there is no concept of an individual persecutor or a person being persecuted, but it means the system should be rejected and removed from the society"14. And overall, "modern terrorism is a rebellion against the ideals of the Western dogmatic world"

Baudillard quotes the following proofs to support the arguments presented above:

1. The Western World claims that the existence of superpowers provide peace and stability in the world. On the other hand, terrorists performing the attack on WTC indicated and emphasized the fact that at any time they can destroy the most symbolic place in the world.

2. The Western World creates and develops globalization and terrorists being confined in their locality highlight their traditional customs and values.

See more: T. Szlendak, Terroryzm oczami socjologa (w:) W. Kwiatkowska-Darul (red:), Terroryzm, Toruń 2002, pp. 53-63.

8 W. Grotowicz, Terroryzm w Europie Zachodniej, Warszawa 2000, p. 84.

9 See more: T. Szlendak, Terroryzm oczami socjologa (w:) W. Kwiatkowska-Darul (red:), Terroryzm, Toruń 2002, p. 59.

10 See more: S.P. Huntington, Zderzenie cywilizacji, Warszawa 2000, p. 90.

11 Development of non-legal concept of explaining the essence of terrorism is the deliberate treatment, which aims to expand the publication of a law, other intellectual currents described dealing with the subject.

J. Baudrillard, Duch terroryzmu. Requiem dla Twin Towers, Warszawa 2005, pp. 1-10.

J. Baudrillard, op. cit., p. 9.

P.A. Redpath, Nieświęta Trójca współczesnego terroryzmu: utopijne marzenia, samoofiarowanie i systemowe zło, (w:) A. Maryniarczyk i inni, Terroryzm - dawniej i dziś, Lublin 2010, p. 33

$15 \quad$ I. Pospiszyl, op. cit., p. 82.
} 
3. The Western World seeks to progress, both technologically and economically, the terrorists on the other hand, favour the traditions established in the past.

4. The Western World advocates stability and continuous development. Terrorists answer this with destructive attacks on public facilities.

5. The Western World glorifies temporal existence emphasizing an apotheosis of the cult of eternal youth, whereas terrorists are not afraid of death, they find it a part of life ${ }^{16}$.

The considerations referenced in the aforementioned study, support the thesis of N. Abbagnano - the Italian existentialist who more than thirty years ago said that "at the root of terrorism lies hopelessness for the further improvement of social life and in order to overcome evil from its nest, external sources have to be provided to the members of society" ${ }^{17}$.

According to Abbagnano, contemporary terrorists begin to identify "society with the evil equated. When we are in favour of direct confrontation with evil, our goal is not to reach an agreement but an attempt to destroy it by all possible means"18.

Therefore, the basic ideology of modern terrorism has become a direct confrontation between the System and the world of ideals where terrorists function. The ideal world - as terrorists perceive it - is an Utopian dream. However, Abaggnano clearly states: the terrorist's Utopia is a myth of the moment which constantly returns in the history of a man - the myth of the miraculous Eden. Absolutization of the Utopia, in the conviction of terrorists, is an act of good faith, like that of an assistant surgeon force to intervene in an operation to rescue a sick organism. Neither do surgeons or terrorists have pity. They only have one aim in life: to sink the scapel into the flesh, to cut away and remove the organ causing the illness ${ }^{19}$.

Terrorists desire the destruction of the existing Euro-Atlantic order, so as to ruin it totally and build from scratch a perfect new world free of blemishes. In this way, terrorists wish to universalize and unify shared ideals and values. According to Boudillard, such assumptions are in contradiction to the fundamental building blocks of every social order which is based on the principle of continuous and unconditional exchange. Boudillard claims that if some values become monopolized then the exchange will cease to function and ultimately it will lead to destruction of the existing social order because there will always be groups which act oppositely, rejecting existing law and order.

16 I. Pospiszyl, op. cit., p. 82.

17 P.A. Redpath, Nieświęta Trójca współczesnego terroryzmu: utopijne marzenia, samoofiarowanie i systemowe zło, (w:) A. Maryniarczyk i inni, Terroryzm - dawniej i dziś, Lublin 2010, p. 34

18 P.A. Redpath, op. cit., p. 34.

19 P.A. Redpath, op. cit., p. 34. 
A one - dimensional world tends to dogmatize and challenge dogma which does not possess rational arguments and a pragmatic way of thinking. It will be sufficient to replace the existing dogma with another that is equally attractive. That is why, terrorist groups or individual perpetrators set the rules of the game, since a single act of terrorism destroys generally professed values in the civilized world.

Baudillard also refers his concept to global order, claiming that this order declines. The new taxonomic order in the author's opinion will burst out from within through negative social phenomena, such as minorities, ethnic groups, local criminal groups, etc. In the world's dominant ideology, terrorist try to preserve the existing order. The need it to ensure that the citizens are subjected to restrictions in civil rights, increased surveillance and progressive state intervention in their private lives. The need to dominate safety and security, and this opinion from Baudillard's view, is the beginning of the end of globalization ${ }^{20}$.

\section{The example of nationalist terrorism in Bosnia, Albania and Kosovo}

The foregoing considerations support the thesis that terrorism is motivated by nationalist motive ${ }^{21}$ (especially in the Islamic dimension), which finds fertile ground among marginalized social groups such as ethnic minorities, discriminated ethnic groups or fundamentalist religious associations, ignored by the leading Western European ideology as a potential source of threat to international security.

Islamic terrorists clearly expose their centuries-old traditions, customs, religious practices and inflexible social structure. This applies not only to the groups originating from Arab or Islamic countries but also covers the Balkan region which for historical, geographical and political reasons, rests within two worlds - Christian and Muslim² ${ }^{22}$; between the Byzantine and the Islamic-Turkish tradition.

This issue refers to a particular areas of Bosnia and Herzegovina, the former Serbian province of Kosovo (now the Republic of Kosovo) and Albania where Muslim cultural stigma is clearly visible.

Ethnic conflicts between the Balkans and Kosovo caused the place to be an ideal for the development of nationalist terrorism, and the profession of Islam by the

\footnotetext{
20 I. Pospiszyl, op. cit., p. 82.

21 Albanian terrorism can be categorized as ethno-nationalist terrorism, which generally plays an important role in European countries and the Middle East, the source of terrorist activity are complex conflicts on grounds of nationality. 
Kosovo Albanians also makes the region vulnerable to the development of Islamic terrorism ${ }^{23}$.

The Balkans also provide an excellent social facility for recruiting activities which for decades has played host to training camps run by Al-Qaeda. Then the Islamic fundamentalists became indigenous inhabitants of the region, which the AFP agency defined as "terrorist heaven" (white European people with blue eyes) ${ }^{24}$.

\section{Bosnia}

The Islamist society was promoted in the seventies of the twentieth century by Alija Izedbeković, a Bosnian political leader during the existence of Yugoslavia. In 1970 he wrote his prolific work: Islamic Declaration - The Islamisation of Muslims and Muslim people. One of the far-reaching objectives depicted in this declaration was the creation of Muslim state in Europe and the establishment of Islamic governance in these areas. Furthermore, U.S. intelligence sources made it clear that Izedbeković closely followed the philosophies of Iranian spiritual leaders.

"After the takeover of power by Khomeini in 1979, Izedbeković intensified his efforts to establish an Islamist government in Bosnia and therefore was arrested by the Communists in 1983"25. In 1990 Izedbeković founded the Party of Democratic Action (SDA), and then won the election and became president of Bosnia and Herzegovina. During the ongoing war, his government continued to disseminate the principles of radical Islam, calling for a Holy War based on the principles of Jjihad with the support of Al-Qaeda.

Moreover, since the early nineties Al-Qaeda began to infiltrate Islamic TAN (transnational networks of support) in Bosnia and Herzegovina, promoting the ideals of deepening Islamization of Bosnian society. Al-Qaeda sought to create a support base for Muslim terrorism. Bosnia has become a great marina and hatchery for Islamic terrorism in Europe. This information was confirmed by intelligence from Sarajevo which registered the presence of training camps for future Islamic terrorists (organized by the mujahideen), near Bihacia, Maglaja and Zenica ${ }^{26}$.

Moreover, many Islamic militants appeared in Bosnia during the ongoing conflict, Bosnian Muslims, calling for Holy War on the principles of Jihad (wahabist

See more: about Islamic terrorism M. Nizioł-Celewicz, Terroryzm, M. Pietraś, Międzynarodowe stosunki polityczne, Lublin 2006, pp. 531-571.

24 S. Kalitowski, Terroryzm na Bałkanach i w Kosowie, http://www.terroryzm.com/article/445/Terroryzm-naBalkanach-i-w-Kosowie.html visit on 2.03.2011.

25 A. Beinsen, Muslimanstvo and „Bosiakdom: Islam in the discourse of Muslims in Bosnia-Hercegovina, SouthEast Review 2002, nr 1, p. 20.

26 S. Kalitowski, Terroryzm na Bałkanach i w Kosowie, http://www.terroryzm.com/article/445/Terroryzm-naBalkanach-i-w-Kosowie.html, visit on 2.03.2011. 
views propagated simultaneously). To-date, the exact number of foreign mujahidden involved in Bosnia remains unknown, although it is stated that there were between 1,500 and 5,000. In one of the IGC reports, the number is given as 3,000.

Typically, they were religious fanatics of high morals, well-trained and experienced combatants. According to experts, many of them were war veterans from Afghanistan ${ }^{27}$. Foreign mujahideen were overwhelmingly responsible for the war Crimes committed, and it was against this backdrop that the proposal to the International Criminal Court for crimes in former Yugoslavia was developed. Three former Commanders of the Army of Bosnia-Herzegovina, were indicted: Enver Hadżihasanović, Mehemed Alagić and Amir Kubura ${ }^{28}$. The trial did not result in convictions.

The Islamic extremists mentioned above had obtained Bosnian citizenship. Amongst those later detained by U.S. authorities, were two of the leaders of Al-Qaeda - Khalid Sheik Mohammed, and the world's most notorius terrorist, Usama Ibn Laden ${ }^{29}$. To this day it remains unclear just how, and how many people were granted Bosnian citizenship both during the war and after its cessation, as the relevant documents were destroyed by employees of the then Bosnian Foreign Ministry. Naturalized Bosnians still remain a potential source of terrorist attacks. In 2001, Special Services arrested several Bosnians associated with Al-Qaeda, and in 2004, they provided a list of 741 individuals who permanently or temporarily reside on the territory of Bosnia and who are suspected of terrorism ${ }^{30}$. Moreover, among them were the perpetrators of attacks in Madrid and in London, who were also tiedin with radicals living in Serbian Kosovo and Sandžak.

27 R. Bachora, Bośnia i Hercegowina państwem upadłym? Kwestia ekstremizmu muzułmańskiego, (w:) M. Gniazdowski (red:), Europejski Protektorat? (Bośnia i Hercegowina w perspektywie środkowoeuropejskiej), Warszawa 2008, pp. 123-140.

28 Hadzihasanovic and Kubura (IT-01-47) Case Information Sheet, 8 november 2005, www. un.org, visit on 8.06.2011.

29 Bin Laden and the Balkans - The Politics of Anti-Terrorism, Balkan Report (Internacional Crisis Groupe z 9 listopada 2001, nr 119, p. 10. Essential for the financing of arms and mujahideen in Bosnia was the organization of the Third World Relief Agency (TWRA), which was to regard as a fundamentalist Muslim, and had its headquarters in Vienn Essential for the financing of arms and mujahideen in Bosnia was the organization of the Third World Relief Agency (TWRA), which was to regard as a fundamentalist Muslim, and had its headquarters in ViennD. Farah, The Role of Sudan in Islamist Terrorism:a Case study, 13 April 2007, www.strategycenter.net/ research/pub visit on 8.06.2011.

30 R. Bachora, Bośnia i Hercegowina państwem upadłym? Kwestia ekstremizmu muzułmańskiego, (w:) M. Gniazdowski (red:), Europejski Protektorat? (Bośnia i Hercegowina w perspektywie środkowoeuropejskiej), Warszawa 2008, p. 123-140. 


\section{Albania and Kosovo}

Nowadays the presence of Islamic fundamentalism is also seen in Kosovo ${ }^{31}$. They perform their activities with the help of Islamic NGO's, offering social and financial aid to local people. This is a particularly attractive form of support, since the people of Kosovo were struggling for many years with economic and political problems. Among the most attractive of NGOs, is the International Islamic Relief Organization which participates in funding the construction costs of ne mosques, organizes the Islamic theology school and facilitates trips to Egypt, Pakistan an Syria in order to study the Koran and practice vahabistic views. The supporters of vahabistic's Views, created a group called "Vahabije" 32 , which was strongly associated with the "Red Rose" organization. "Vahabije" acted mainly in the region of Raska (Bosnia), trying to extend its influence into areas of Serbia.

Generally, at the beginning of the last decade, special services have registered mujahideen activities in the Balkan region. Many of them took part in the Balkan war on the side of Bosnian Muslims. They created the Seventh Brigade - Mujahedeen ${ }^{33}$, whose members committed numerous murders against Serb and Croat citizens of former Yugoslavia.

After the war, the presence of Al-Qaeda and vahabistic's organization in the movements in the Balkan area receded, although the country is still regarded as a recruitment base (this includes Albania, Bulgaria, Macedonia, Kosovo and Bosnia and Herzegovina, and Sanjak region). The most significant leader of the underground terrorist in the Balkans is Ajman Al Zavahiri, whose presence has also been noted in Turkey, Albania, Macedonia, Bulgaria and Kosovo.

Albanian's nationalism in connection with Islam is regarded as extremely dangerous, and has been observed for more than a decade in specific countries of the former Yugoslavia, especially in Kosovo. At the beginning of the century the largest organization of Albanian nationalists was the Albanian National Army (AKSh), which possesses troops in Kosovo, Southern Serbia and Northern Greece ${ }^{34}$.

31 In early March 2011, Two soldiers en route to Afghanistan were shot dead at Frankfurt airport and another two injured.The perpetrator of the attack was a 21-year-old Astrid Uka- Abańczyk Kosowski. Preliminary investigation showed that this was a single perpetrator of an act motivated by Islamic radicalism. The case remains pending. See more. www.gazetaprawna.pl visit on 4.04.2011.

32 Patrz szerzej: http://www.balkanistyka.org/macedonia/artykuły/ visit on 7.03.2011.

33 S. Kalitowski, Terroryzm na Bałkanach i w Kosowie, http://www.terroryzm.com/article/445/Terroryzm-naBalkanach-i-w-Kosowie.html Kmdr ppor. Sebastian Kalitowski - a former commander of a specialist group of divers in the Navy's elite 'Formoza'unit. In 2003-2005 he was in charge of combat missions in Kosovo, and he now operates a private company - Maritime Safety \& Security Ltd - which provides advice on maritime security; the protection of facilities and ships from terrorist attack and the training of crews on how to respond under acts of terrorism and piracy, (http://www.maritime-security.eu/).

34 S. Kalitowski, Terroryzm na Bałkanach i w Kosowie, http://www.terroryzm.com/article/328/Albanska-ArmiaNarodowa-AKSh.html visit on 27.03.2011. 
Albanian's terrorist organization AKSH (Armata Kombetare Shqiptare), is the result of the division of the National Liberation Army (NAW) in 2001, after signing the "Ohrida Framework Agreement". The leader of the Albanian insurgents - Ali Ahmeti, signed the agreement which obliged members of organization to cease terrorist operations. Nevertheless, many members rejected the contents of the agreement and continued to fight, transforming their group into the Albanian National Army (ANA) ${ }^{35}$.

The most important aim of the organization is realization of the dream "Great Albania", covering within its scope all Balkan terrains inhabited by Albanians; Kosovo, the north-west region of Macedonia (Tetovo and Kumanovo district), the south-west region of Serbia (Presevo Valley), the south-eastern part of Montenegro and Northern Greece (the region known as Cameri). The organization was supported by the Albanian party - Front for Albanian National Unification (FBKSH), whose leader was Gafur Adili aka Valdet Vardari, with Idajet Beqiri aka Alban Vjosa (an Albanian lawyer), holding the position of Secretary ${ }^{36}$.

Adili and Beqiri, propagated the idea of "Great Albania" and the compatible idea of "Ethnic Albania" 37 . They intended to promote their requests either through diplomatic channels or by means of armed struggle, if the international community ignored their "right ideas". In addition, members of the organization were informed of the possibility of carrying out terrorist acts during the Olympics Games in Greece (2004). Ultimately, that threat was not fulfilled.

The organization had material and logistics facilities predominantly in Kosovo where they conducted numerous recruiting raids among the local Albanian population. Moreover, its members committed numerous acts of violence against the Serb minority.

AKSH cooperated with former members of the Liberation Army Preseva, Medveda and Bujanovca (UCPMB), in the Presevo Valley in southern Serbia. In 2003 this organization was proclaimed a terrorist group, under the direction of Michael Steiner - leader of the UN Mission In Kosovo (UNMIK). This was a direct consequence of the destruction of a railway bridge in Zvecan on 12th April 2003, using an explosive device. AKSH claimed responsibility for the attack.

The severity of terrorist activities performed by Albanian militants led to mobilization of the Macedonian Albanian special forces. As a result, Gafur Adili

35 S. Kalitowski, Albańska Armia Narodowa (AKsH), http://www.terroryzm.com/article/328/Albanska-ArmiaNarodowa-AKSh.html visit on 27.03.2011.

36 S. Kalitowski, Albańska Armia Narodowa (AKsH), http://www.terroryzm.com/article/328/Albanska-ArmiaNarodowa-AKSh.html visit on 27.03.2011.

37 M. Wandelberg, Rozbicie Jugosławii (jugosłowiańskie lustro międzynarodowej polityki), Warszawa 2005, pp. 246-251. 
(Valdet Vardari), leader of the popular Front for Albanian National Unification (FBKSH), the political wing of the Albanian National Army (ANA), was arrested. In the territory of Macedonia (FYROM) ${ }^{38}$ Gafur Adili has been accused of "incitement to hatred between people of different races and faiths, counterfeiting currency and forging officia documents".

Moreover, Albanian police obtained evidence that he was also buying weapons for AKSH. Another combat success against the Albanian National Army was the arrest of Idajeta Bergiri, - leader and founder of the Party of National Unity, wanted by Interpol for inciting ethnic hatred in mass-media. Overall, Albanian terrorist groups function on the basis of specific principles of customary law, which in turn reflect tribal and clan structures of Albanian society.

These rules, based on traditional tribal customs, known as kanunu, when combined with fundamentalist Islam, result in an extremely volatile mixture. Of course, this mainly applies to residents of the mountain regions not to Albanian society as whole, which resides in the larger cities and modernizes very quickly. The principle of the Albanian code of honor still finds its followers and continuators. Most of its rules are consistent with the rules of fundamentalist Islam (although their origin is different) and traditional tribal values, advocated by Islamic terrorists (see Baudillard's discussion).

Albanian clans consist exclusively of family members and without blood ties a person cannot join a clan. The clans operate in accordance with the rules of the Kanunu code of honor, which, since the Middle Ages, minutely regulated every sphere of the Albanian highlanders life, ranging from family life to the functions of social life. The rhythm of their existence was subordinated by the seasons and directly related to sheep grazing. However, this cycle was often disturbed by the numerous wars which absorbed vast number of victims. Relatives of the victims were obliged to seek bloody revenge which activated successive acts of hatred. In its original form, kanunu survived until the end of nineteenth century ${ }^{39}$.

During the Ottoman domination, young generations of Albanians assumed power from the elders, establishing their own clans. The Albanian communist authorities ruthlessly combated all manifestations of tribal culture by organizing a social structure based on the principles of the philosophy of Marxism and Stalinism. Today the most cruel kanunu rules survive; bloody revenge, ruthless command of obedience, loyalty and secrecy. Albanian criminals, on the basis of these rules, form a hermetically closed group, where infiltration is virtually impossible. The situation

38 M. Szkolak, Wejście do NATO pod nazwą FYROM, http://www.psz.pl/index.php?option=com_content\&task=view\&id=4794 visit on 20.03. 2011.

39 M. Waldenberg, Rozbicie Jugosławii (jugosłowiańskie lustro międzynarodowej polityki), Warszawa 2005, s. 173-178, R. Holbrooke, The End a War, New York 1998, p.151. 
is further complicated by the fact that Albanians do not require to use code as their native language does not belong to any language family and is one of a kind. This generates problems with the rapid translation of information gained from wiretaps.

A social group constructed in such a way, has become extremely attractive in terms of potential criminal activity. Taking place in the nineties of the twentieth century, the war in the Balkans provided many opportunities for the development of crime. Military actions resulted in Balkan smuggling routes being used for purposes that were quickl seized upon by members of the Albanian clans. In the communist period, the clan were involved in the organized smuggling of contraband between Albania, Yugoslavia and Greece. NATO aggression directed at Serbia in 1999, created even greater scope for the criminal activities of clan members by opening up broad opportunities outside of Albania and Kosovo (mainly in neighboring countries: Greece and Turkey).

\section{Cross-border organized crime in the Balkans, with particular consideration to the Republic of Kosovo}

The apogee of Albanian mafia activity occurred in the period between 1999 and 2000. The Albanians subjugated several independent criminal groups engaged in drug trafficking in the countries comprising the former Yugoslavia. There are important assumptions that members of Albanian organized criminal groups, supported and organized the Albanian resistance movement in Kosovo, which was later transformed into the Kosovo Liberation $\mathrm{Army}^{40}$.

Many Army members were involved in criminal activity. The unilateral decision of Kosovo Albanians to declare independence in Kosovo in 2008, cemented the position of the Albanian mafia throughout the Balkan region. Albanian criminal groups effectively control the Balkan route, which begins in Central Asia, runs through Turkey, Greece and Kosovo, and thence into the Slavic countries - Poland included. The countries of final destination are in Western Europe; Germany, The Netherlands, Switzerland, etc. In Kosovo, where 95 percent of goods are imported, smuggling became a major source of income for both the local population as well as for organized criminal groups engaged in drug trafficking.

Kosova Albanians serve a crucial role in the long chain connecting the Afghan poppy farmers with the refiners and with the Western heroin market. Drugs from Afghanistan arrive first in Iran, where they are taken over by Turkish Albanians, who in turn pass on the 'goods' to Macedonian Albanians, who smuggle them into

40 M. Waldenberg, Rozbicie Jugosławii (jugosłowiańskie lustro międzynarodowej polityki), Warszawa 2005, pp. 262-272. 
Kosova. In Kosova, the bulk consignment is divided and repacked into smaller quantities for distribution. The target countries of course, are those of Western Europe and the U.S. ${ }^{41}$

The practice of drug trafficking has been described in a report concerning the activities of the United Nations Office on Drugs and Crime (UNODC), against the Albanian mafia, which indicates that the heroin trade is its main source of income. However, according to police statistics, there has been a decline in the demand for heroin in Europe which reflects the decreasing number of Albanians tracked and arrested during investigations of heroin trafficking.

The UNODC report estimates that in the early twenty-first century, due to the dominance of Albanians in the market, heroin was overpriced. Nowadays, Albanian criminal groups control 10-20 percent of the heroin market in Europe. From the Balkans region as a whole, 60 percent of heroin is destined for markets in Western Europe. Kosovo is a crucial stopover on this route ${ }^{42}$.

Albanian clans control the drug trafficking business. As previously mentioned, the organization possesses its own internal hierarchical structure, which is based on the patriarchal family model working on its own account, and which takes advantage of the fact that its members reside outside the country.

In Albania and Kosovo, particular families control key thoroughfares, and thereby the main smuggling routes. In this way, the whole of Kosovo and Northern Albania is divided up amongst the clans.

This thesis is confirmed by international reports made by the European division of the UN drug agency situated in Vienna. The police and special services from Switzerland, Germany and the U.S. have pointed to the fact that smuggling is especially developed in countries with a significant number of Albanian immigrants. The report confirms that since NATO's intervention in the Balkans, Albanian criminal groups have engaged in the trafficking of persons, drugs, arms, and cigarettes. The presence of such criminal groups in Western Europe is also acknowledged in Interpol statistics - in the EU, around 27 thousands Kosovo Albanians are detained in prisons ${ }^{43}$.

Europol, the EU police agency, in its reports on the structure of the criminal world in the EU - published annually for over ten years now, estimates that local mafias have the strongest influx in EU countries, with the Albanian mafia ranking as a leader. This is confirmed by data contained in an UNODC report published in

41 Jędrzej Winnicki, Kosowo Nostra, Tygodnik Polityka nr 15 (2700) from 11 April 2009, p. 107-109.

42 A. Balcer, Wszechpotężna mafia albańska to mit, http://wyborcza.pl/1,76842,6937076,Wszechpotezna_mafia_ albanska_to_mit.html\#ixzz1GCXCpsCy, odczyt z dnia 20.03.2011.

43 Jędrzej Winnicki, Kosowo Nostra, Tygodnik Polityka nr 15 (2700) from 11 April 2009, p. 107-109. 
late May, 2008. According to this report, in nrecent years political stability in the Balkans led to a gradual weakening of local criminal structures. However, there are still state structures formed in Kosovo which are not conducive to the overall stability of the region.

The second source of income for Albanian criminal groups is human trafficking ${ }^{44}$, mainly women who are forced into prostitution on premises belonging to members of the mafia. During the Balkan wars, the victims came from developed centers for refugees. Currently, women are recruited from the former Soviet Union and the CIS ${ }^{45}$. Some of them are minors under sixteen years of age the number of women forced into prostitution remains unknown but allegedly continues to increase. Several years ago, the International Organization for Migration (IOM), ${ }^{46}$ claimed that 120,000 women are trafficked annually across the Balkans, including those trafficked by the Albanian mafia, in order to work in brothels in the West. Converseley, the UNODC report ${ }^{47}$ considers this number to be overstated and argues that the annual figure is around 25,000. ${ }^{48}$ Albanian criminal groups are also involved in the trafficking of human organs. In February 2011, American and British media reported the arrest of Dr Yusuf Sonmez, a Turkish citizen, was the subject of a Red Notice issued by Interpol that called for his arrest with a view to extradition in connection with an investigation being conducted by the European Union into trafficking in Kosovo.

In that case, the allegations concerning illegal transplant procedures have already involved seven people, mostly local doctors from Pristina but also the health secretary of Kosovo and an Israeli doctor. Sonmez, was not charged but prosecutors said that he played a key role throughout the whole project. In 2008, Sonmez worked as a surgeon in a private clinic, Medicus, in the capital of Kosovo - Pristina. Officers discovered that he had performed illegal kidney transplant procedures, for which the beneficiaries had paid up to $€ 90,000$ per kidney. It was estimated that some 20 organs were transplanted in this way.

The case of Medicus clinic was merged with a much more sensational investigations, namely human organ trafficking during the Balkan war. A Parliamentary Assembly of the Council of Europe developed a report in which it states that some members of the Kosovo Liberation Army (KLA) - including current

44 Definitions of trafficking was included in the so-called. Palermo Protocol (Protocol to Prevent, Suppress and Punish Trafficking in Persons, Especially Women and Children supplementing the UN Convention against Transnational Organized Crime, adopted by the United Nations General Assembly of 15 November 2000 (Dz.U.z dnia 2005 r. Nr 18, poz. 160). On trafficking, see more: Z. Lasocik, Handel ludźmi, Warszaw 2006, p. 1-10.

45 Leszek Szymanowski, Ośmiornice europejskie, internetowe czasopismo Stosunki międzynarodowe z dnia 07.02.2002, odczyt z dnia 10.03. 2011. http://www.stosunki.pl/?q=node/479

46 See: IOM, http://www.iom.int/jahia/Jahia/activities/europe/south-eastern-europe/unsc-resolution-1244-administered-kosovo/cache/offonce/ visit on 28.04.2011.

47 See: ttp://www.unodc.org/unodc/en/about-unodc/annual-report.html, Raport 2009, 2010, odczyt z dnia 28.04.2011.

48 Adam Balcer, Wszechpotężna mafia albańska to mit, http://wyborcza.pl/1,76842,6937076,Wszechpotezna_ mafia_albanska_to_mit.html\#ixzz1GCXCpsCy visit on 28.04.2011. 
Prime Minister Hasim Thaci Kosovo), detained Serb prisoners in secret camps in Albania. Prisoners were shot in the head and their bodies smuggled to Istanbul. The report was based on evidence gathered by intelligence services and witness's testimony. The report's findings clearly show links between criminal groups and Medicus clinic ${ }^{49}$.

The special services in the Balkan states, despite their successes in the fight against organized crime, did not prevail in this phenomenon, primarily because a particularly difficult situation exists in Kosovo where the Alabanian mafia linked to local policies, is in fact in control of the state structures. This state of affairs has been maintained since NATO's intervention in the Balkans, and despite operations in the region by the UN administration, and now by the European EULEX mission, the institutions concerned are unable to control the activities of criminal groups in Kosovo. It seems legitimate to claim, therefore, that the youngest European state has become the safest haven for the most efficient criminal organizations in Europe.

\section{Albanian organized crime and the world of local politics}

Kosovo is a specific case, primarily because of the numerous links of politics with the criminal world. These relationships reach to the highest level in this country, with both president and prime minister being involved in criminal activity. Furthermore, almost very prominent Albanian speaking politician in Kosovo, is linked either directly or indirectly with the war crimes committed during the war with Serbia. The current ruling class derives from the former members of the Kosovo Liberation Army (UCK), an organization having all the characteristics of a delinquent. ${ }^{50}$

At the top are the Kosovar politicians who have in their resumes infamous and obscure threads. There is the Kosovo Prime Minister, Hashim Thaci, who is the alleged head of the so-called "drenicka's group which deals with illegal fuel sales, car theft, drug trafficking and human trafficking. Members of the Prime Minister's clan "take care of" the Drenica valley stretching from the south of Kosovo, and the territories west of Pristina, which belong to the former head of the Kosovo government, Remusha Haradinaj. In connection with the Prime Minister's alleged criminal activities, Haradinaj, was indicted by the International Criminal Tribunal for crimes in the former Yugoslavia. However, the matter remains unresolved since previously gathered evidence was not confirmed in court as the witnesses, prior to

49 Doreen Carvajal, The International Herald Tribune /fakty.interia.pl/news/potwor-czy-ratujacy-zyciechirurg,1594225 visit on 8.06.2011.

50 See more: M. Wandelberg, Rozbicie Jugosławii (jugosłowiańskie lustro międzynarodowej polityki), Warszawa 2005, pp. 262-272. 
testimony, died in unexplained circumstances. This phenomenon is widely described in the book of the former prosecutor of the Court - Carla Del Ponte ${ }^{51}$.

Another Kosovar politician implicated in illegal business ${ }^{52}$ is the current president of Kosovo, Behgjet Pacolli, who took office on 22 February 2011. Pacolli, a Kosovar immigrant who after many years spent in Western European countries (Germany, Austria, Switzerland) and who has a Swiss passport, returned to his native homeland. As the owner of a construction company, Pacolli received many lucrative contracts, including contracts in Russia and in the Asian republics of the former USSR. In the nineties, the President was associated with Pavel Borodin who is now a secretary of the Union of Belarus and Russia. Pacolli received numerous concession contracts in Russia, including those related to renovation of the Kremlin. According to the findings of Swiss prosecutors, this investment was acquired through gigantic bribes and the case involved both Pacolli, and Borodin, as well as other associates of former Russian President, Boris Yeltsin ${ }^{53}$.

As a leader of the Alliance New Kosovo Party, Pacolli began his political career with the function of deputy to the Parliament of Kosovo (2007). Subsequently he joined in the coalition agreement with the Democratic Party of Kosovo. Having gained the support of its leader, Prime Minister Thaci - Pacolli became the most serious candidate for the presidency. However, Pacolli was only officially elected as president of Kosovo after a third poll. Previously, all of the candidates failed to gather the required majority of votes. Only sixty-seven MPs voted from the onehundred and twenty eligble. The opposition boycotted the elections, mainly due to Pacolli's ties with Russia, which to-date does not want to recognize Kosova as an independent country. Ultimately, the selection of Pacolli as president was questioned by the Kosovo Constitutional Court which stated that was invalid due to lack of a quorum, and rival, during the poll. Pacolli accepted the verdict to be valid and resigned $^{54}$.

The character of the former president of Kosovo has raised many doubts and controversies. The Serbian press, has regularly reported his activities, commencing with the incredible story of his attempt to corrupt Martti Ahtisaari. Pacolli also tried to persuade the government of the Maladives to recognize Kosovo by offering it a large sum of money. Pacolli himself claims that the friendly gesture from the Maldives government was the result of skilful diplomatic negotiations which, in the

51 Ł. Kobeszko, Poważne zarzuty pod adresem premiera Kosowa, http://www.psz.pl/index.php?option=content\&ta sk=view\&id=35628, Carla del Ponte, Polowanie. Ja i zbrodniarze wojenni, Książka została objęta szwajcarską cenzurą, MSZ zakazał jej publikacji.

52 Also regarded as one of the godfathers of the Albanian mafia in Kosovo who washes dirty money through a chain of banks and insurance companies. Jędrzej Winnicki, Kosowo Nostra, Tygodnik Polityka nr 15 (2700) from 11 April 2009, pp. 107-109.

53 Jędrzej Winnicki, Kosowo Nostra, Tygodnik Polityka nr 15 (2700) from 11 April 2009, pp. 107-109.

54 Prezydent Kosowa podał się do dymisji (pol.). Gazeta Wyborcza, 2011-03-30. [dostęp 2011-03-30]. 
long-term, would result in the recognition of Kosovo by other Asian and African countries.

\section{Albanian organized crime and the world of local politics}

The above considerations present the passage of reality played out in areas covered for many years by a major national-ethnic conflict. The scale of the problems that have grown against this background is very "impressive", starting with local organized groups engage in the trafficking of humans, drugs and weaponry, through to the Albanian drug cartels, and ending with the highest number of representatives involved in criminal activities. The modus operandi of Albanian criminal groups is mostly based on the principles of tribal loyalties (the kanunu code) which has existed for centuries and which requires absolute obedience to the code and the defense of honor, usually by numerous acts of aggression.

This pattern favors the development of a cultural crime, and creates a favorable field for terrorist activities, examples of which are included in this study. It is also to be hoped that the new structure of this the youngest European state,,will ultimately prov stronger than the organized criminal groups and terrorist organizations. 


\section{MIĘDZYNARODOWY TERRORYZM I PRZESTĘPCZOŚĆ ZORGANIZOWANA NA BAŁKANACH - PRÓBA DIAGNOZY ZJAWISKA}

Niniejszy artykuł dotyczy związków pomiędzy transgraniczna przestępczością zorganizowaną a terroryzmem na terenie półwyspu Bałkańskiego. W pierwszej części pracy znajdują się rozważania na temat teoretycznych koncepcji terroryzmu, ze szczególnym uwzględnieniem ujęcia tematu na podstawie koncepcji J. Baudillarda oraz N. Abbagnano. Druga część opracowania zawiera opis zjawiska terroryzmu nacjonalistycznego, na przykładzie wybranych krajów bałkańskich. W części trzeciej zaś znalazły się rozważania dotyczące reislamizacji bośniackiego społeczeństwa, którą to datuje się od połowy lat sześćdziesiątych ubiegłego wieku. Część czwarta artykułu natomiast została poświęcona problematyce Republiki Kosowa, na terenie którego obserwuje się działalność nie tylko mudżahedinów, czy wahabitów, ale także albańskich organizacji terrorystycznych (np. Albańskiej Armii Narodowej, Armii Wyzwolenia Presera, Medveda i Bujanovca). W opisywanej części (jako podrozdział) zamieszczono także informacje o albańskich zwyczajach plemiennych (albański kodeks honorowy: Kanun) recypowanych przez albańskie zorganizowane grupy przestępcze. Specyfikacja procederów przestępczych owych grup ewaluowała od klasycznej kontrabandy, poprzez handel narkotykami, bronią, handel ludźmi skończywszy na handlu ludzkimi organami. Ponadto szczególną cechą charakterystyczną albańskiej przestępczości zorganizowanej działającej na terenie Kosowa jest ścisłe powiązanie świata przestępczego z politycznymi strukturami Republiki Kosowa. Tekst zamykają wnioski końcowe.

Key words:

Republic of Kosovo, Republic of B\&H, Balkan's terrorism, Albanian criminal groups, Albanian corruption, cross border organized crime 